\title{
LITERARY PORTRAIT GENRE IN ANAR'S ART
}

Mammadova Elnara Elkhan ${ }^{1}$

\begin{abstract}
In all his art, Anar turns to the genre of literary portrait as one of the forms of artistic and documentary narrative of memorial-biographical literature. Anar's task is to create complete and reliable impression about any outstanding person, his character, place in society, shown in the context of a certain time and space. The hero of literary portrait of Anar is real person with real biography, whose personal and creative fate the writer produces through his perception, using both documentary and artistic means. Literary portraits of Anar make it possible to study this genre as independent one, consisting in the experience of genre synthesis, where the author's concept of the world and human is expressed most clearly.
\end{abstract}

Keywords: literary portrait genre, Azerbaijani literature, Anar's art, genre synthesis, artistic and documentary narration.

\section{Introduction}

In all his art, Anar gives special attention to the richest cultural heritage of his people, the nature and development of which he studies from the point of view of individual outstanding persons who lived and worked in different periods of development of national history. In order to do it, he often use the literary portrait genre as one of the forms of artistic and documentary narration. Usually literary portrait of Anar consists in a model of the world, reflecting the author's concept of created character. In this regard, the consideration of the features of literary art of Anar makes it possible to present the features of the worldview positions of modern people in the conditions of growing interdependence and integration.

The purpose of this article is to analyze the artistic features of literary

\footnotetext{
${ }^{1}$ Sumgayit State University, Head Teacher of the Faculty of Literature of Azerbaijan and Foreign Countries. Email: metodist.az@ mail.ru. ORCİD: https://orcid.org/0000-00024010-4774
} 
portraits in the art of modern Azerbaijani writer Anar, based on his works, since one of the main genre trends in the development of modern world literature as a whole is referring to literary portrait as a way of determining moral and aesthetic characteristics of a hero.

The scientific novelty of this approach is associated with the comprehension of main directions of personal development of modern human, with the possibilities of demonstration of person in the wide information space, in the conditions of the interdependence and integration which become closer day by day. The spirit of the time, recognized by the writer, demonstrates itself namely in portrait sketches, where main features of modern person, aspiring to the creation of new humanistic characteristics, are captured.

\section{Development}

The phrase "literary portrait" ("portraitlitteraire") was introduced into the literature by Sainte-Beuve, who began to create "literary portraits" of "geniuses", creative "minds" [Anar, 2012]. In Russian literature, N.A.Polevoy is considered as the first practitioner and theorist of this genre, who actively turned to biographical materials when analysing creative writing. He created a number of literary portraits of G.R.Derzhavin, V.A.Zhukovsky, A.S.Pushkin and several others, and later, these literary portraits were combined in the book called "Essays on Russian Literature" [Markova O.V., 1988]. In this book the writer's work was considered in close unity with his life, person, age. Further, such a genre, which is based on the combination of creative and personal origins, allowing you to create holistic view of certain artist, outstanding person, was established in literary terminology as a "literary portrait", designating one of the genre formations.

The "Concise Literary Encyclopaedia" defines a literary portrait as "a documentary essay about a writer, artist and outstanding public figure" [Baraxova V.S., 1985]. Researchers are constantly make corrections to the definition of the genre, adjusting it. For example, V.S.Barakhov gives the following definition: "a literary portrait is an artistic holistic characteristic of certain real person in the form of a memorial essay that creates an idea about his/her individually unique, 
living appearance, about his/her character" [Baraxova V.S., 1985]. O.V.Markova defines a "literary portrait" as "a complex synthetic formation that develops on the border of art and documentary genres" [Markova O.V., 1988].

As one of the forms of the writer's memorial-biographical prose, literary portraits, being synthetic genre, built on a combination of documentary and artistry and having their own specific ways of creating the character, consist in classic examples of this genre, certainly enriched by creative person of their author, his/her creative manner.

\section{Methodological Bases of Research.}

In order to disclose, ground current goal, various methods, including comparative analysis, methods of describing the artistic image were used in the research. The research referred to scientific and theoretical practice of Azerbaijani literary studies, turned to the methods of creating of artistic portrait of scientists. Scientific and methodological basis of the research is the thoughts of general theoretical significance of outstanding scientists, literary scholars, main principles of artistic and analytical analysis in Azerbaijani literature.

\section{Discussion}

The task of Anar when writing a literary portrait is to create by means of verbal art the most complete and reliable impression about certain outstanding person, his character, place in society, shown in the context of a certain time and space. The hero of the literary portrait of Anar is a real person with real biography. At the same time, this is an image, a line of life, personal and creative fate of which the writer produces through his perception, using both documentary and artistic means. This is the aesthetic essence of literary portrait of Anar, designed to reflect as closely to the reality as possible both external features and the behaviour manner, character, language, thinking, views, whole biography of his hero, but from the point of view of the author's attitude towards this hero.

Literary portrait genre is often equalled with the essay genre or serves in relation to it as a synonymous term. However, an essay is a phenomenon more of journalistic degree, while literary portrait contains elements of 
artistry and is more correlated with fiction, or at least with documentary fiction. To the greatest extent, this is able to be applied to literary portraits of Anar, who brings in them his subjective feelings and sensations, breaking through them his attitude towards the hero. Anar also gives great attention to artistic and visual means, clearly thinking through artistic component, composition and techniques of expressive. For the most part, literary portraits created by Anar, which constitute extensive layer in his comprehensive and rich work.

Literary portraits of Anar were also created based on the biographies of his contemporaries, based on personal impressions of the writer, captured in his memory. These are representatives of the generation of Anar himself (Mammad Araz, Bakhtiyar Vahabzada, Vagif Samadoglu, Alla Akhundova, Elchin etc.), representatives of younger generation, up to the youngest (Afag Masud, Zalimkhan Yagub, Ilgar Fahmi, Elchin Huseynbayli, Gunel Anargizi etc.). However, perhaps, the greatest number of literary portraits is devoted to outstanding persons of the past, people who are separated from the writer by a time distance, sometimes very long time distance.

In case of historical figures, the author designs his "portrait" based on the learning of available information about the hero's biography and activities drawn from various written sources, while the portraits of contemporaries are based on personal observations and even close acquaintance of the writer with the portrayed. Literary portraits of Nizami, Fizuli, Nasimi, Vagif and Vidadi, M.F.Akhundov， G.Zardabi， Natavan, J.Mammadguluzadea Sabir, H.Javid etc. are able to be considered as such portraits. Arranged in chronological order, these portraits in common give an idea about the development of Azerbaijani literature, starting with "Dede Gorgud" up to date.

Usually, the headings of literary portraits belonging to many writers is the name of the portrayed. Anar also has such headings that immediately let you know the name of the hero. These are literary portraits of "'Where is Nizami? Every verse will answer "He is here"", "A Word about Yusif Vazir", "Reflecting about Mehdi Huseyn" etc. However, more often, the heading of literary portrait by Anar expresses the 
essence of character, the main trait of the hero, dominant feature that distinguishes him from others, and determines the concept of character in the perception of Anar.

For example, literary portrait devoted to the rebel poet, freethinker Nasimi is called "The Feat of the Poet." "The Victory of the Poet" is the heading of the portrait of Shah Ismail Khatai, the poet and ruler who reigned for 23 years and marched from victory to victory. The portrait devoted to the greatest lyric poet, singer of love and torment arisen from it, Fizuli, called "The Sorrow of the Poet". The portraits of Vagif and Vidadi are produced under one heading - "Singer of pleasures, singer of sorrows".

This union of two major poets in one work is not accidental. Both poets lived in the same age, were friends, and even related, having married their children. However, at the same time, Vagif was a singer of material pleasures, swinger and a sybarite; and Vidadi was a poet whose poems were painted in sorrowful tones. "Memories about the Sower" is literary portrait of Zardabi, the publisher of the first Azerbaijanilanguage newspaper Ekinchi (Sower). In addition, the portrait of the long- suffering Huseyn Javid, the greatest dramatist who created priceless examples of tragedy, is called "The Tragedy of the Author of Tragedies."

Thus, Anar's search line for the key moment of the person of the people portrayed by him, the conceptual feature of certain person is determined already in the heading. However, comprehensive image in the unity of his creative and personal characteristics, the place of this artist and his views in the context of time, socio-political, ideological views, environment and circumstances both of personal and public nature, reveals in the text of the portrait.

Each of the portraits of historical figures created by Anar has individual colours, which is specified by the appearance of the hero's person. However, at the same time, all portraits of Anar have common typological features. First, all of them are characterized by certain plot fragmentarily. In each individual case, the writer highlights the most expressively certain individual aspects of creative person. However, at the same time, in each portrait created by Anar there is the author's concept of the character of the hero based on the 
available facts of his biography, and the time and space in which the hero lived and created are reflected. Second, the narrative structure of each portrait, irrespective of in which age his hero lived, clearly expresses the inner world of the narrator himself, his attitude to the depicted.

In this regard, we can show as typical example literary portrait of Khurshid Banu Natavan, called by Anar "Wounded monument, wounded memory". The name of the poetess, Natavan who was the daughter of the last ruler of Karabakh Mehdigulu Khan, is firmly connected with Shusha. Speaking about it, Anar writes: "At present, when the road to Shusha has been prohibited for us because of Armenian occupation, Shusha, this city of my love, youth and work in my mature years, makes me groan every string in my wounded soul" [Anar, 2012].

This is a view from the present, a bridge between the past and the present, between us and Natavan, who lived in the $19^{\text {th }}$ century, between Shusha of Natavan and Shusha of Anar. Thus, the author also becomes one of the characters in the portrait, and therefore an object of the image for the reader.
And the name of literary portrait reflects actual fact of the bullet-ridden monument of Natavan, which once adorned Shusha, and therefore of our memory.

In literary portrait of Anar, the fact of real biography without prejudice to the objectivity of the content is enriched to some extent by the creative imagination of the author. His portrait is similar to the novel, since it reflects the fate of man in time and space. However, unlike the novel, the image of the author is more activated. Reading literary portraits of Anar, one comes to the conclusion that researchers who think that "Structural plan of the genre represents that level of artistic harmony at which the "transition" of the reality material to artistic image takes place, its "recoding" is being implemented" are right [Urtiminseva M.Q., 2005].

The "novelistic nature" of Anar's portraits expresses itself in writing out by the writer the life path of his heroes, the most difficult vicissitudes of their personal life. We learn about the sad of Nizami, who lost his beloved wife - the beautiful Kypchak Afet and found solace in his son, about Nasimi's love to real material pleasures, about his painful 
death in Aleppo, that "Shah Ismayil never smiled from the date of the Battle of Chaldiran until his death - whole ten years" [Anar, 2012].

We learn from the portrait devoted to Zardabi how he knocked the thresholds of the rich men to raise money to help needy students and for the newspaper, we learn about his first love, his life and death with detailed description of magnificent funeral that he did not want to give even a little amount for Zardabi's educational projects. In the artistic and integral image of a person, the uniqueness of his internal and external appearance, thinking, language, character, manner of behaviour in everyday life, in his creative activity, the aesthetic essence of literary portrait genre of Anar is revealed.

Anar, creating his literary portraits, uses various techniques to create the reader's visual impression about the hero. Sometimes this happens through a show of appearance, but more often - direct author's characterization, as well as showing actions, demeanour, interpersonal relationships etc. There is certainly discovery and emphasis by artistic means of something individual, unique in the imaging of certain hero, on the other hand, of typical traits of this person and allowing him to be correlated with other similar persons.

Thus, revealing the image of Shah Ismail Khatai, Anar writes: "there were many battles "in his name" since his childhood, many sacrifices were made for Ismail. Being the successor of glorious dynasty, he, as Anar writes, as if "this great person appeared in the world long before his real birth" [Anar, 2012]. Anar calls Nasimi "Renaissance person", this rebel, who rebelled against the orthodox religion, proclaiming "I am God." A poet, philosopher, propagandist of Hurufism and a hero-martyr. This is how Nasimi appears in his main features in literary portrait of Anar. And this specifies many of his actions, his attitude to the world, and as a result, the reader creates a full-fledged, visible idea of this person.

A portrait is often perceived as a way of literary, aesthetic and scientificresearch, since it often allows you to raise very actual problems of literary criticism, history, philosophy, as well evaluate the role and place of certain creative person in the development of national and world literature, culture, art. 
Literary portraits of Anar are especially significant also in this point of view. His literary portraits give an idea not only about certain individuals, but also contain theoretically grounded thinking about Hurrufism, Sufism, medieval literature and philosophy, on the relationship of power and art in different periods of national history, and on much more.

It is no coincidence, that M.I.Andronikova in her book "From Prototype to Image", considering literary portrait genre, noted: "Portrait is a kind of art model of a real concrete person, which reproduces - directly or indirectly - the environment of certain real person, his background, his individually unique connections with the outside world" [Andronikova M., 1974]. In this regard, the portraits of Anar are very demonstrative, since they give an idea of not only private fate of individual person (although it is very important), but they also quite visibly give the context of the age, the atmosphere of time, the tread of history.

Literary portraits of Anar make it possible to study this genre as an independent one, consisting in the experience of genre synthesis, where the author's concept of the world and human is expressed most clearly. Unfortunately, there is still no work in Azerbaijani literary criticism and criticism devoted to the study of the poetics and artistic specificity of literary portrait as the genre of Anar, it is also applicable to Azerbaijani literature. Literary portrait carries enhanced role of the author's origin, therefore, various forms of expression of the author's person (citationality, intertextuality, a combination of different time layers and points of view, etc.) get great role.

Most of all, Anar's authorial position manifests itself in theoretical generalizations that the author makes, discussing certain person, as well in lyrical digressions. This makes the narrative fabric in literary portrait multilayer, depriving it of monotony. Thus, narrative of each of Anar's literary portraits is built on the alternation of strictly objective reasoning and emotionally coloured lyrical digressions.

In determining the genre specificity of literary portrait, fundamental question is the question: "Into which of the genre systems journalistic, artistic-journalistic, or fiction - the researchers include this 
genre. Anar, usually, includes it into artistic-journalistic coordinate system, where in each individual case either the artistic or documentary-journalistic principle prevails. Going from fact, document to artistic comprehension, Anar creates his own concept of character of the individuality of the hero.

The combination of novel and essay, artistic and journalistic thinking, inherent in Anar, allows him to create, manoeuvring between these various systems of verbal art, a unified whole, which every time consists in original mixed genre that combines elements sometimes of several genres. Thus, in literary portrait, organic unity is formed by elements of an essay, and a documentary narrative, and an art essay, and a literary and critical article.

Important feature of the narration in literary portrait of Anar is a combination of several contexts related to each other: personal fate, originality of creativity, features of the age. All these three contexts are invariably involved in each literary portrait, being their typological trait. Thus, in literary portrait devoted to Nasimi, the author exclaims: "This is how this age reflected in the art of contemporary and eyewitness of the
722

occurrences - Imadaddin Nasimi!"

[Anar, 2012].

"They lived at the same time a time of vague, harsh, cruel." [Anar, 2012]. This is the beginning of literary portrait devoted to Vagif and Vidadi, and then the analysis of their personal life and work follows. Based namely on this "triunity" (person, creativity, time) special "plot" of literary portrait is created, a kind of composition is built that allows you to create a complete picture of the hero, and most importantly, "new knowledge" about famous person.

The fight of Anar is in the name of ensuring that the culture of the people, to accommodate time and individual ideological trends, does not become a victim of overthrowers of truths, which has been observed in history at all times, has encouraged him to create priceless "literary monuments" of the leading figures of Azerbaijani literature, art and culture, as well of young, novice writers, of worthy changes that aims to continue the mission of their predecessors. Anar's "literary portraits" artistically reinforce his position, which in polemical form expressed in many of his journalistic articles and speeches. 
In this point of view, public statement of November 5, 1992, signed by Anar together with other 35 cultural figures, is worth a look. It says that national culture "has now found itself in a confrontation, in a fight against the market criteria, market concepts and tastes, with the market level and morality. At present, all the cultural heritage of our people undergoes total audit" [Anar, 2005-2008].

\section{Conclusions}

To sum up the article, we can say that literary portraits created by Anar have the following general parameters: they reveal the nature of real person, documentary facts in them are thought up by the author, each of the portraits has its own stylistics, melodics and intonation, which varies depending on the situations involved in plot, there is the connection into a unified whole in them of the fate of the character, his work and the time in which he lives.

By virtue of its nature, as one of the types of memorial-biographical literature, literary portrait combines the past and the present, producing holistic image of historical time on certain material - the appearance of a hero, who is the embodiment of the time. Literary portrait genre of Anar has a more local structure in comparison with his memory books, about which we will talk below.

\section{Bibliographic References}

Anar (2010). Azerbaijani literature, art and culture. In 3 books Baku: Letterpress

ANar (2005-2008). Works in 5 books. Baku: Yurd.

Andronikova M. (1974). From Prototype to Image. Moscow: Science.

Barakhov V.S.(1985). Literary portrait. Moscow: Science.

Concise Literary Encyclopaedia: in 9 books. (1968). Book 2. Moscow: Soviet Encyclopaedia.

Markova O.V. (1988). Literary portrait as the type of "writer" criticism //Artistic creativity and 
literary process. Publication VIII,

Tomsk.

Polevoy N.A.(1839). Essays on

Russian Literature. Part 2. STb.

Trikov V.P.(1999). French literary portrait of XIX century. Moscow: Science: Flinta.

Urtminseva M.G. (2005). Literary portrait genre in Russian literature of the second half of XIX century: genesis, poetics, typology. Doctoral dissertation abstract, Nizhniy Novgorod 